УДК 338.1

JEL Classification: F17

O. В. ЖУРАВЛЬОВ,

кандидат економічних наук, дочент кафедри менеджменту зовніиньоекономічной діяльності, Національна академія статистики, обліку та аудиту

\title{
Статистичне оцінювання результативності трансформаційних зрушень (на прикладі Сінгапуру): інституційний підхід
}

Стаття присвячена актуальній темі статистичного оцінювання результативності трансформаційних зруиень на прикладі Сінгапуру. Використання регресійного аналізу впливу інституційних факторів на економічне зростання показало, що саме інституційне середовище мас вагомий статистичний вплив на результативність трансформації національной економіки Сінгапуру. На прикладі статистичного оцінювания впливу інституційних факторів на економічне зростання в Сінгапурі підтверджено, що регресійне моделювання с прийнятим способом оцінювання результатів трансформаційних зруиень.

Ключові слова: статистичне очінювання результативності трансформацій, інституційне середовище, економічне зростання, регресійне моделювання.

Постановка проблеми. Статистичне оцінювання результативності трансформацій $€$ i складним теоретичним питанням, і вкрай необхідним компонентом управління національною економічною системою. Повнота оцінки результатів трансформації має грунтуватися на фундаментальних законах економічної теорії. Разом із тим, існує низка факторів, які зазвичай не беруться до уваги, однак відіграють значну роль у статистичному оцінюванні ефективності трансформації.

Найбільш поширений підхід до статистичного оцінювання результативності трансформацій включає традиційні макроекономічні фактори, однак залишає поза увагою фактори інституційні - формальні і неформальні - "правила гри", які і визначають траєкторію економічного розвитку.

Стає очевидним, що статистична наука має поєднувати міждисциплінарні підходи до оцінювання тих трансформаційних зрушень, які відбуваються в світі взагалі та в пострадянсыкому регіоні зокрема. Саме приклад інституційного розвитку в Сінгапурі $\epsilon$ доказом того, що інститути в сучасному глобальному світі все ще мають величезне значення для економічного розвитку.

Таким чином, можна стверджувати, шо систематичний аналіз закономірностей трансформаційних процесів ще не завершений, мають місце дискусії щодо природи, вектора і моделей трансформації. На наш погляд, статистичне оцінювання результативності трансформацій має розглядатися саме через призму інституційного середовища економічних систем.

Аналіз останніх досліджень та пубблікацій. Питанням статистичного оцінювання результативності трансформацій присвячені численні праці зарубіжних вчених, серед яких варто виділити О. Аузана, Б. Вайнгарта, Р. Коуза, Д. Норта, В. Полтеровича, Дж. Уоліса $[2 ; 7 ; 8]$. Слід зазначити, що більшість роб̈іт згаданих авторів присвячена стандартним макроекономічним моделям, у той час як сучасні тенденції в економічній науці на новий рівень виносять аналіз трансформацій через нову інституційну економіку. Цей напрям економічної теорії є опозиційним до некласичного “мейнстриму".

Серед українсыких вчених, що досліджували трансформацію економічних систем, варто виділити роботи С. Архієреєва, В. Геєця, А. Гриценка, О. Осауленка О. Яременка $[1 ; 4 ; 5 ; 6]$.

Вплив інституційних факторів на економічну трансформацію набув нового значення в праці Д. Аджемоглу та Дж. Робінсона “Чому нації занепадають?" [10]. Автори наполягають, що "хоча від економічних інститутів залежить, буде країна бідною чи ба-

(C) О. В. Журавльов, 2017 
гатою, саме політика і політичні інститути визначають вибір цих економічних інститутів. В кінцевому підсумку хороші економічні інститути в США стали наслідком роботи політичних інститутів, які складалися поступово починаючи з 1619 року" [10, с. 40].

В своєї ранній роботі Д. Аджемоглу підкреслює, що “колонізація європейськими поселенцями регіонів світу була вирішальною мірою, що сформувала характер розселення, а також інституційні результати" [10, с. 14].

Л. Стеблякова наголошує, що "загострення протиріч, хаотичність економічної динаміки і наростання хвилі глобальних криз на рубежі тисячоліть обумовлені завершенням індустріального економічного устрою в найбільш розвинених країнах, вичерпанням наявного потенщіалу зростання, нездатністю поки що знайти адекватні відповіді на виклики нового століття, нової епохи і здійснити перехід до розвитку на якісно новій основі" [9, с. 3].

Таким чином, на сучасному етапі з'явилася нова тенденція у дослідженні і оцінюванні трансформації економічних систем через призму нової інституційної теорії, а для певних країн, у т. ч. для Сінгапуру, інституційне середовище $\epsilon$ базовою конщепщію економічних перетворень, що і потребує подальшого дослідження.

Метою дослідження $є$ поглиблення теоретичних підходів до оцінювання результативності трансформації в Сінгапурі через призму нової інституційної теорії.

Викладення основного матеріалу дослідження. Проблема вимірювання трансформації різниться в залежності від регіону світу і сталості розвитку капіталізму і ринкової економіки.

На вимогу Президента Франції в 2008 р. було створено дослідницьку групу, до складу якої увійшли Й. Стігліц, Ж.-П. Фетуссі, Ж. Сен, які запропонували схему з 8 показників для оцінювання результативності економічних змін (рис. 1):

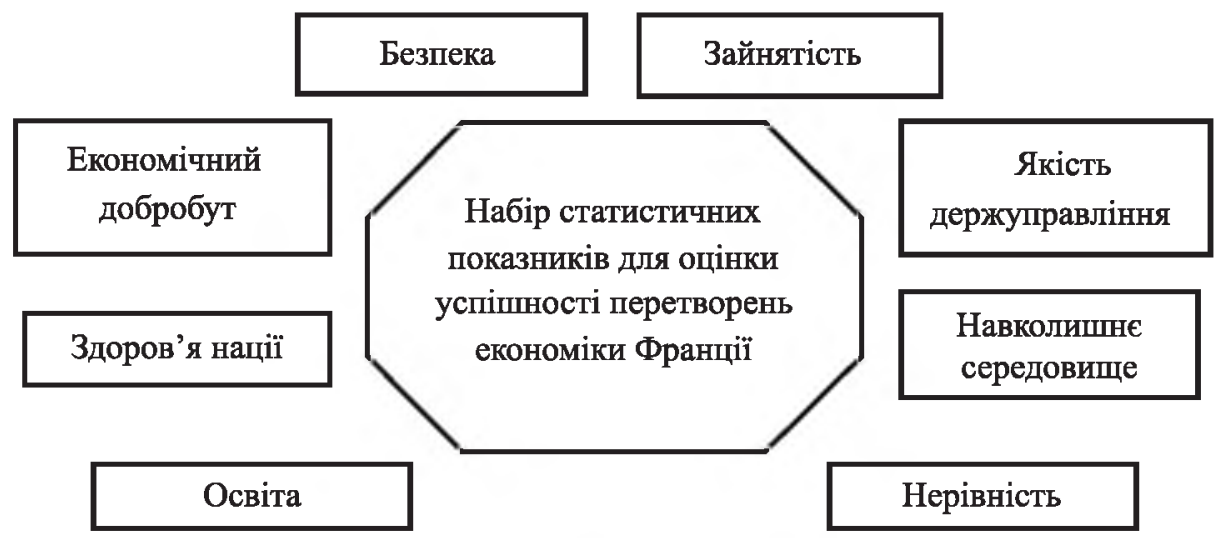

Рис. 1. Система індикаторів Й. Стігліца, Ж.-П. Фетуссі, Ж. Сена

Для визначення впливу інституційного середовища на трансформацію економічних систем нами запропоновано розширити цей перелік показників, щоб забезпечити можливість його використання для країн, різних за рівнем економічного розвитку і інституційного середовища (табл. 1).)

Розширений перелік показників для оцінювання впливу інституційного Табличя 1 середовища на трансформацію економічних систем

\begin{tabular}{|l|l|}
\hline \multicolumn{1}{|c|}{ Показник } & \multicolumn{1}{c|}{ Опис } \\
\hline Політична стабільність & Індикатор Світового банку. Коливається в межах від -2,5 до 2,5. \\
\hline Економічна свобода & Загальний індекс економічної свободи складається з десяти \\
& компонентів, згрупованих у три основні категорії: верховенство \\
& закону; ефективність регулювання і відкриті ринки. Загальна \\
& економічна свобода оцінюється за шкалою від 0 до 100, де \\
& 100 - максимальна свобода. \\
\hline
\end{tabular}




\begin{tabular}{|c|c|}
\hline & \\
\hline Фіскальна свобода & $\begin{array}{l}\text { Індекс фіскальної свободи вимірює податкове фіскальне } \\
\text { навантаження. Складається з трьох кількісних факторів: верхня } \\
\text { гранична ставка податку на доходи фізичних осіб, верхня } \\
\text { гранична ставка податку на прибуток юридичних осіб; загальне } \\
\text { податкове навантаження у відсотках від ВВП. }\end{array}$ \\
\hline Людський розвиток & $\begin{array}{l}\text { Індекс ООН, що вимірює три основні аспекти людського } \\
\text { розвитку: довге і здорове життя, знання і гідний рівень життя. } \\
\text { Для розрахунну індексу використовуютьяя чотири показники: } \\
\text { очікувана тривалість життя при народженні, середня кількість } \\
\text { років навчання, очіку вана тривалість навчання та валовий } \\
\text { національний доход на душу населення. }\end{array}$ \\
\hline Відкритість торгівлі & Експорт + імпорт, \% ВВП \\
\hline Умови торгівлі & $\begin{array}{l}\text { Індекс ЮНКТАД, що показує чисті бартерні операції. } \\
\text { Розраховується як відсоткове відношення індексів вартості } \\
\text { одиниці експорту до індексів вартості одиниці імпорту, } \\
\text { вимірюється відносно базового року } 2000 \text {. }\end{array}$ \\
\hline Економічна глобалізація & $\begin{array}{l}\text { Індекс економічної глобалізації вимірює фактичні економічні } \\
\text { потоки і обмеження для торгівлі і капіталу }\end{array}$ \\
\hline Політична глобалізація & $\begin{array}{l}\text { Індекс політичної глобалізації вимірює кількість посольств і } \\
\text { високих комісій у країні; кількість міжнародних організацій, у } \\
\text { яких вона є членом; кількість миротворчих місій ООН, в яких } \\
\text { країна бере участь. Індекс також включає кількість договорів, } \\
\text { підписаних між країною та іншими міжнародними партнерами } \\
31945 \text { року. } \\
\end{array}$ \\
\hline Соціальна глобалізація & $\begin{array}{l}\text { Індекс соціальної глобалізації складається з трьох компонентів, } \\
\text { що оцінюють: ступінь особистих контактів через кордони } \\
\text { за допомогою переміщення, міграції, грошових переказів та } \\
\text { інших засобів; потік інформації між країною і рештою світу } \\
\text { з точки зору телекомунікацій через телебачення, Інтернет, } \\
\text { пошту та інші канали; культурну близькість країни до інших } \\
\text { країн через доступ до міжнародних фільмів, музики та інших } \\
\text { засобів масової інформації. }\end{array}$ \\
\hline Економічне зростання & зростання ВВП від попереднього року, \% \\
\hline $\begin{array}{l}\text { Споживання } \\
\text { домогосподарств }\end{array}$ & $\%$ ВВП \\
\hline Частка послуг в В1ВП & $\%$ ВВП \\
\hline Безробіття & \% від працездатного населення \\
\hline $\begin{array}{l}\text { Частка жінок в трудових } \\
\text { ресурсах }\end{array}$ & \% від працездатного населення \\
\hline $\begin{array}{l}\text { Кілыкість Інтернет } \\
\text { користувачів }\end{array}$ & Фактична кількість \\
\hline $\begin{array}{l}\text { Кількість нових } \\
\text { автомобілів }\end{array}$ & Фактична кількість \\
\hline Ціна на паливо & дол. США \\
\hline Верховенство права & Індикатор Світового банку. Коливасться в межах від -2,5 до 2,5. \\
\hline Використання енергії & Умовні одиниці \\
\hline $\begin{array}{l}\text { Ефективність } \\
\text { державного управління }\end{array}$ & Індикатор Світового банку. Коливається в межах від -2,5 до 2,5. \\
\hline Контроль корупції & Індикатор Світового банку. Коливається в межах від -2,5 до 2,5. \\
\hline Сприйняття корупції & Індикатор Світового банку. Коливається в межах від -2,5 до 2,5. \\
\hline Громадські свободи & Індикатор Світового банку. Коливається в межах від -2,5 до 2,5. \\
\hline $\begin{array}{l}\text { Очікувана тривалість } \\
\text { життя }\end{array}$ & $\begin{array}{l}\text { Очікувана тривалість життя при показує кількість років, які } \\
\text { проживе новонароджений. }\end{array}$ \\
\hline \% протестантів & \% від кількості віруючих \\
\hline Витрати на освіту & $\%$ ВВП \\
\hline
\end{tabular}

Джерело: систематизовано автором 
Особливістю збирання статистичної інформації для нашого дослідження $є$ іiї нерівномірність у часі - інституційні індикатори почали розраховуватися відносно нещодавно, в той час як традиційні макроекономічні індикатори для країн Західної Свропи доступні з початку XX століття.

Нами запропоновано статистичне оцінювання Сінгапуру в т. ч. через достатність i повноту статистичних даних як національної статистики, так і міжнародних організацій.

Багато в чому успішна економічна трансформація Сінгапуру обумовлена поєднанням трьох унікальних факторів: Сінгапур є невеликим островом-державою; Сінгапур історично розташований на перетині торгових шляхів Південно-Східної Азії; перший президент Сінгапуру Лі Куан Ю створив ефективну структуру державного управління [3].

Економіка Сінгапуру являє собою розвинену ринкову систему, яка залежить від експорту продукції, особливо в таких галузях як побутова електроніка, інформаційні технології, фармацевтика і фінансові послуги. Економіка Сінгапуру також є однією 3 найбільш відкритих і вільних від корупції економік. Дані щодо динаміки економічного розвитку Сінгапуру наведено на рис. 2.

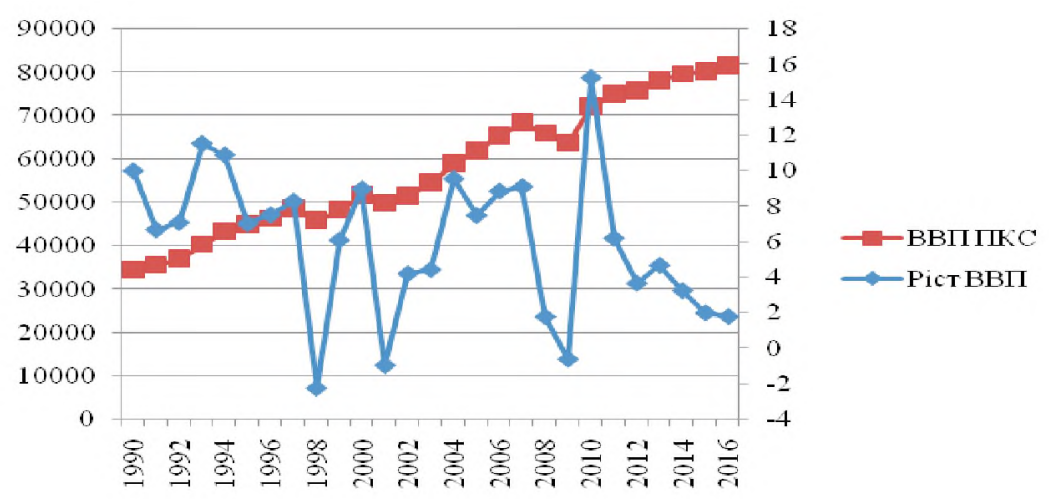

Рис. 2. Динаміка економічного зростання і ПКС Сінгапуру Джерело: [11]

Середній темп зростання ВВП Сінгапуру в період з 2004 по 2008 рік склав 6,8\%, але в 2009 році через світову фінансову кризу знизився до 2,1\% (рис. 2).

Боротьба 3 корупцією в Сінгапурі почалася шляхом лібералізації нормативноправового регулювання бізнесу, покращення умов роботи та підвищення зарплати суддів, оновлення складу поліції, підвищення зарплат держслужбовцям на відповідальних посадах до рівня топ-менеджерів у приватному секторі, створення незалежного органу з боротьби з фінансовим розкраданням в вищих ешелонах влади (Агентства боротьби з корупцією) [1].

Трансформація економічної системи Сінгапуру протягом останніх майже тридцяти років обумовила подальше зростання частки послуг у ВВП (рис. 3).

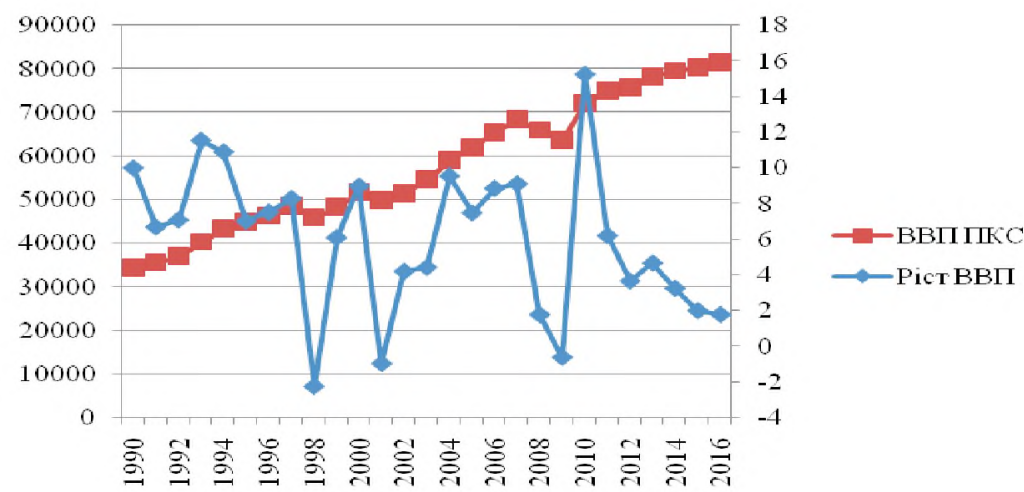

Рис. 3. Частка промисловості і послуг в ВВП Сінгапуру, \% Джерело: [3] 
Відкритість торгівлі Сінгапуру залишається однією з найвищих у світі (рис. 4). Через значну частку експорту Сінгапур відчуває велику залежність від коливань кон'юнктури світового ринку, особливо ринків США, Китаю і Європи.

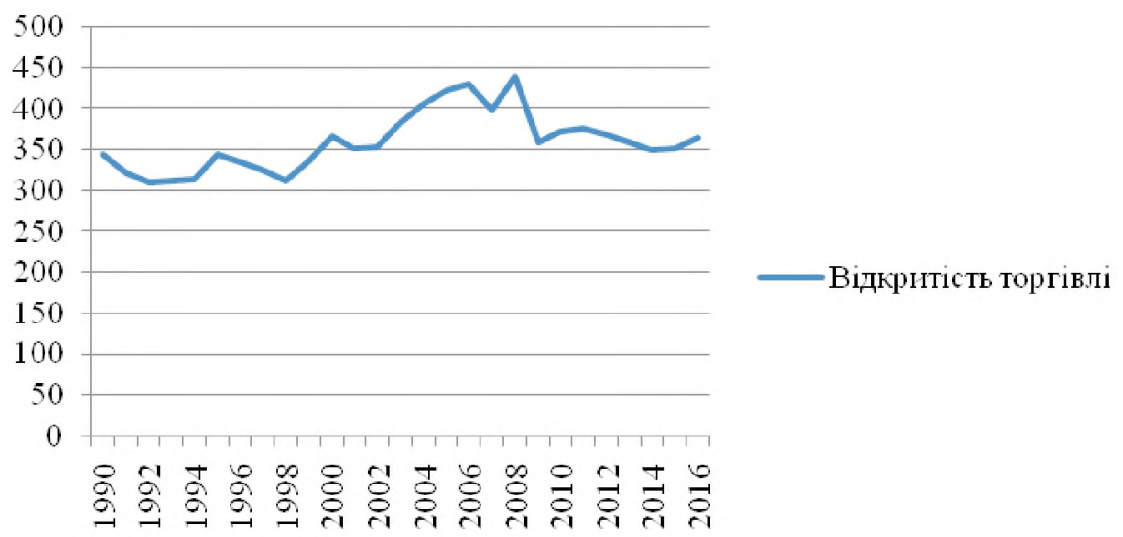

Рис. 4. Динаміка відкритості торгівлі Сінгапуру

Джерело: [11]

Особливим викликом для Сінгапуру був стрімкий економічний підйом Китаю та зростання конкурентоспроможності інших країн АСЕАН. Це вимагало від економіки Сінгапуру структурної адаптації через переорієнтацію на високотехнологічні галузі та підвищення продуктивності виробництва Основними статтями експорту та імпорту Сінгапуру є верстати, технологічне оснащення та приладдя до них (зокрема електронні компоненти), нафтопродукти і хімікати. Зручне розташування Сінгапуру і першокласна інфраструктура його порту зробили це місто одним з найбільших в світі контейнерних портів поряд із Гонконгом і Шанхаєм.

Нами запропоновано оцінити наступну теоретичну модель для Сінгапуру.

Економічне зростання $\mathrm{Y}=f$ (цивільні свободи, рівень корупції, економічна свобода, економічна глобалізація, рівень витрат на освіту, використання енергії, частка жінок на ринку праці, фіскальна свобода, ціна на паливо, ПКС, ефективність державного управління, рівень споживання, індекс людського розвитку, кількість користувачів Інтернету, тривалість життя, безробіття, відкритість торгівлі).

$$
\mathrm{Y}=\mathrm{X}_{1}+\mathrm{X}_{2}+\ldots \mathrm{X}_{17}+\mathrm{c}
$$

Перевірка часових рядів на стаціонарність, яка проводилася в пакеті EViews8 за методом Філіпса - Перона, показала результат, відображений у табл. 2.

Таблиця 2

Результати тестів на стаціонарність за методом Філіпса - Перона

\begin{tabular}{|c|c|c|c|c|c|c|c|c|}
\hline \multicolumn{8}{|c|}{ Phillips - Perron test } & \multirow[b]{2}{*}{ energyuse } \\
\hline & proth & civillib & contrcor & econfre & ecglob & ecgrow & eduspend & \\
\hline c & $* * *$ & - & $*$ & $*$ & - & - & $*$ & $* *$ \\
\hline $\mathrm{ct}$ & $* * *$ & - & $*$ & $*$ & - & - & $*$ & $* *$ \\
\hline$c-$ diff & $* * *$ & $* * *$ & $* * *$ & $* * *$ & $* * *$ & $*$ & $* * *$ & $* * *$ \\
\hline $\mathrm{ct}-$ diff & $* * *$ & $* * *$ & $* * *$ & $* * *$ & $* * *$ & $*$ & $* * *$ & $* * *$ \\
\hline \multicolumn{9}{|c|}{$* \mathrm{p}<0.10 ; * * \mathrm{p}<0.05 ; * * * \mathrm{p}<0.01$} \\
\hline \multicolumn{9}{|c|}{ Phillips - Perron test } \\
\hline & femlab & Fiscalfr & Gaspr & gdpppp & goveff & housecons & Humdev & Interusers \\
\hline $\mathrm{c}$ & - & - & - & - & - & - & $* * *$ & $* * *$ \\
\hline $\mathrm{ct}$ & - & - & - & - & - & - & $* * *$ & $* * *$ \\
\hline $\mathrm{c}-\operatorname{diff}$ & $* * *$ & $* * *$ & $* *$ & $* * *$ & $* * *$ & $* * *$ & $* * *$ & $* * *$ \\
\hline $\mathrm{ct}-$ diff & $* * *$ & $* * *$ & $* *$ & $* * *$ & $* * *$ & $* * *$ & $* * *$ & $* * *$ \\
\hline
\end{tabular}




\begin{tabular}{|l|l|l|l|l|l|l|l|l|}
\hline \multicolumn{8}{|c|}{ Phillips - Perron test } \\
\hline & lifeexp & Polglob & polstab & prrights & rulelaw & $\%$ serv & socglob & termstr \\
\hline $\mathrm{c}$ & $* * *$ & - & - & - & - & - & $* * *$ & - \\
\hline $\mathrm{ct}$ & $* * *$ & - & - & - & - & - & $* * *$ & - \\
\hline $\mathrm{c}-$ diff & $* * *$ & $* * *$ & $* * *$ & $* * *$ & $* * *$ & $* * *$ & $* * *$ & $*$ \\
\hline $\mathrm{ct}-$ diff & $* * *$ & $* * *$ & $* * *$ & $* * *$ & $* * *$ & $* * *$ & $* * *$ & $*$ \\
\hline$* \mathrm{p}<0.10 ; * * \mathrm{p}<0.05 ; * * * \mathrm{p}<0.01$ \\
\hline
\end{tabular}

\begin{tabular}{|l|l|l|}
\hline \multicolumn{3}{|c|}{ Phillips -P erron test } \\
\hline & tradeopeness & Unemployement \\
\hline $\mathrm{c}$ & - & - \\
\hline $\mathrm{ct}$ & - & - \\
\hline $\mathrm{c}-$ diff & $* * *$ & $* * *$ \\
\hline $\mathrm{ct}-$ diff & $* * *$ & $* * *$ \\
\hline$* \mathrm{p}<0.10 ; * * \mathrm{p}<0.05 ; * * * \mathrm{p}<0.01$ \\
\hline
\end{tabular}

Джерело: розраховано автором

Ті часові ряди, що були ідентифіковані як нестаціонарні, взято в перших різницях.

Регресійну модель (1) було оцінено за методом найменших квадратів. Результати представлено в табл. 3 .

Таблиия 3

Результати регресійного моделювання за методом найменших квадратів

\begin{tabular}{|c|c|c|c|c|}
\hline \multicolumn{4}{|c|}{ Dependent Variable: D(ECONOMIC GROWTH) } & \\
\hline \multicolumn{3}{|l|}{ Method: LeastSquares } & & \\
\hline Variable & Coefficient & Std. Error & t-Statistic & Prob. \\
\hline $\mathrm{C}$ & -1069.057 & 356.7948 & -2.996280 & 0.0957 \\
\hline D(CIVIL LIBERTIES) & 5.506326 & 3.139066 & 1.754129 & 0.2215 \\
\hline CONTROL OF CORRUPTION & -41.00800 & 8.499661 & -4.824663 & 0.0404 \\
\hline ECONOMIC FREEDOM & -3.902148 & 0.632930 & -6.165217 & 0.0253 \\
\hline D(ECONOMIC GLOBILAZATION) & -4.891739 & 0.904998 & -5.405250 & 0.0326 \\
\hline EDUCATION SPENDING GDP & 24.44309 & 2.682100 & 9.113416 & 0.0118 \\
\hline ENERGY USE & 0.004467 & 0.001404 & 3.182899 & 0.0861 \\
\hline D(FEMALE LABOUR FORCE) & 0.555093 & 1.146120 & 0.484324 & 0.6760 \\
\hline D(FISCAL FREEDOM) & -6.315367 & 0.558760 & -11.30247 & 0.0077 \\
\hline D(GDP PPP) & -0.001182 & 0.000214 & -5.519606 & 0.0313 \\
\hline D(GOVERNMENT EFFECTIVNESS) & 38.06684 & 5.209545 & 7.307133 & 0.0182 \\
\hline $\begin{array}{l}\text { D(HOUSEHOLD CONS GDP) } \\
\text { (HOLO }\end{array}$ & -0.370158 & 0.271048 & -1.365655 & 0.3054 \\
\hline HUMAN DEV & 51.90682 & 32.39356 & 1.602381 & 0.2502 \\
\hline INTERNET USERS & -1.007426 & 0.284348 & -3.542932 & 0.0713 \\
\hline LIFE EXPECTANCY & 4.605118 & 2.147983 & 2.143927 & 0.1653 \\
\hline D(POLITICAL STABILITY) & -5.861669 & 6.905914 & -0.848790 & 0.4854 \\
\hline PROTH & 70.43888 & 17.93038 & 3.928466 & 0.0591 \\
\hline D(RULE OF LAW) & -50.25753 & 10.31184 & -4.873770 & 0.0396 \\
\hline R-squared & 0.797439 & \multicolumn{2}{|c|}{ Meandependentvar } & -0.286500 \\
\hline Adjusted R-squared & 0.775674 & \multicolumn{2}{|c|}{ S.D. dependentvar } & 6.264634 \\
\hline S.E. ofregression & 0.777079 & \multicolumn{2}{|c|}{ Akaikeinfocriterion } & 2.288916 \\
\hline Sumsquaredresid & 1.909365 & \multicolumn{2}{|c|}{ Schwarzcriterion } & 3.185075 \\
\hline Loglikelihood & -4.889156 & \multicolumn{2}{|c|}{ Hannan-Quinncriter. } & 2.463855 \\
\hline F-statistic & 45.82722 & \multicolumn{2}{|c|}{ Durbin-Watsonstat } & 3.107258 \\
\hline Prob(F-statistic) & 0.021557 & & & \\
\hline
\end{tabular}

Джерело: розраховано автором 
Результати регресійного моделювання дозволяють нам виділити фактори, які виявилися статистично значущими i, відповідно, можуть бути інтерпретовані: контроль корупції, економічна свобода, економічна глобалізація, витрати на освіту, використання енергії, фіскальна свобода, кількість користувачів Інтернету, верховенство права, частка протестантів серед релігійних меншин у Сінгапурі.

Економічна інтерпретація статистичного оцінювання результатів економічної трансформації в Сінгапурі має такий вигляд:

- якість інституційного середовища має вирішальне значення для економічного розвитку Сінгапуру. Контроль корупції, економічна свобода та глобалізація, верховенство права зумовлюють економічне зростання в Сінгапурі. Водночас статистичний вплив цих факторів має різну спрямованість - від негативної до позитивної (табл. 3). На наш погляд, це пояснюсться особливістю моделювання з використанням змішаних даних, що мають натуральний вигляд і тих, що взяті в перших різницях;

- зростання видатків на освіту позитивно впливає на економічне зростання;

- економічне зростання Сінгапуру знаходиться у високій позитивній залежності від рівня споживання енергії.

Висновки і подалыші дослідження. Інституційне середовище $є$ можливою призмою дослідження результатів та ефективності трансформації, і тому інституційна статистика стає важливою складовою для емпіричних досліджень в економіці.

Крім того, важливим фактором стало політичне і соціальне становище в країні після здобуття незалежності в 1965 р., шо сприяло проведенню системних реформ у державі.

Проте з досвіду Сінгапуру можна винести деякі універсальні уроки. Найбільш очевидним $\epsilon$ важливість ефективного управління, будь то в державних або квазідержавних структурах. Розвиток інфраструктури вимагає від політичних лідерів рішучості і прагнення до досягнення швидкого економічного прогресу. Здатність державного сектору планувати і реалізовувати інфраструктурні проекти є результатом компетентності кадрів та ефективного фінансового управління, а нетерпимість до корупції стає наріжним каменем розвитку.

Статистичне оцінювання з позиції нової інституційної теорії ускладнено тим, що й досі в економічній літературі відсутній єдиний набір індикаторів, оцінювання яких привело 6 до точного виявлення впливу інституційного середовище на економічну трансформацію та економічне зростання.

Разом із тим, на прикладі статистичного оцінювання впливу інституційних факторів на економічне зростання в Сінгапурі підтверджено, що регресійне моделювання $€$ прийнятим способом оцінювання результатів трансформаційних зрушень. Отримана модель виявилася адекватною і працездатною.

\section{Список використаних джерел}

1. Архиереев С. И. Трансакционные издержки и неравенство в условиях рыночной трансформации. Х.: Бизнес-Информ, 2000. 288 с.

2. Аузан А., Келимбетов К. Социокультурная формула экономической модернизации // Вопросы экономики. 2012. № 5. С. 53-58.

3. Беседин К. В. Сингапурская модель экономики для развития бизнеса на современном этапе // Молодой ученый. 2015. № 2. С. 253-255.

4. Гайдай Т. Неоінституціонализм та його аналітико-дослідницький потенціал // Економіка України. 2003. № 9. С. 60-66.

5. Геєць В. М. Нестабільність та економічне зростання. К.: Ін-т екон. прогнозув., $2000.344 \mathrm{c}$.

6. Гриценко А. Особливості інституційної архітектоніки українського суспільства XXI століття // Економіка України: Стратегія і політика довгострокового розвитку. За ред. акад. НАН України В. М. Гейця. К.: Ін-т екон. прогнозув., Фенікс, 2003. $1008 \mathrm{c}$.

7. Норт Д., Уоллис Дж., Вайнгаст Б. Насилие и социальные порядки. Концептуальные рамки для интерпретации письменной истории человечества. М.: Институт Гайдара, 2011. $480 \mathrm{c.}$

8. Полтерович В. М., Попов В. В. Демократизация и экономический рост // Общественные науки и современность. 2007. № 2. С. 13-27. 
9. Стеблякова Л. П. Трансформация экономических систем: теория и практика : автореф. д. э. н. : 08.00.01. М., 2010. $56 \mathrm{c}$.

10. Acemoglu D., J. Robinson Why Nations Fail: The Origins of Power, Prosperity, and Poverty. New York: Crown Publishing Group, 2012. 575 p.

11. Statistical Data. The Global Economy [Electronic Resource]. URL: http://www.theglobaleconomy.com/Singapore/kof_econ_glob/

A. В. ЖУРАВЛЕВ, кандидат экономических наук, доцент кафедры менеджмента внешнеэкономической деятельности, Национальная академия статистики, учета и аудита

\section{Статистическое оценивание результативности трансформационных сдвигов (на примере Сингапура): институциональный подход}

Статья посвяцена актуальной теме статистического оценивания результативности трансформационных сдвигов в примере Сингапура. Использование регрессионного анализа влияния институциональных факторов на экономический рост показало, что именно институциональная среда имеет весомое статистическое влияние на результативность трансформации национальной экономики Сингапура. На примере статистического оченивания влияния институциональных факторов на экономический рост в Сингапуре подтверждено, что моделирование является приемлемым способом оценивания результатов трансформационных изменений.

Ключевые слова: экономическая система, статистические показатели, глобализация, статистическое моделирование, институциональные факторы.

\section{O. V. ZHURAVLYOV, PhD (Economics),}

Associate Professor of Department for Management of Foreign Economic Activities National Academy of Statistics, Accounting and Audit

\section{Statistical Assessment of the Effectiveness of Transformation Change (by Case of Singapore): Institutional Approach}

In studies of economic transformations and their statistical assessment, the causality of processes specific to economic relations and development of institutions is overlooked. The article is devoted to the important topic of statistical assessment of the transformations effectiveness. The case of Singapore is taken because it is an Asian country demonstrating the essential role of the institutional environment in the national economy transformations. The regression analysis of the impact of institutional factors on economic growth in Singapore is made using 17 indicators: civil freedoms, corruption, economic freedom, economic globalization, spending on education, use of energy, share of women at labor market, fiscal freedom, price for fuel, PPP, effectiveness of public administration, level of consumption, Human Development Index, Internet users, life expectancy, unemployment, openness of trade. Economic interpretation of the statistical assessment of economic transformations in Singapore is as follows: quality of the institutional environment (control of corruption, economic freedom, supremacy of law etc.) has critical importance for economic development in Singapore; the increasing spending on education has positive effects for economic growth in Singapore; economic growth in Singapore has high positive correlation with energy consumption.

Keywords: economic system, statistical indicators, globalization, statistical modeling, institutional factors.

Посилання на статтю:

Журавльов О. В. Статистичне оцінювання результативності трансформаційних зрушень (на прикладі Сінгапуру): інституційний підхід // Науковий вісник Національної академії статистики, обліку та аудиту: зб. наук. праць. 2017. №1-2. С.7-14. 